DOI 10.37882/2223-2982.2021.11.05

\title{
ПРОМЫШЛЕННОЕ ПРЕДПРИНИМАТЕЛЬСТВО КРЕСТЬЯН В УЕЗДНЫХ ГОРОДАХ ТУЛЬСКОЙ ГУБЕРНИИ ВТОРОЙ ПОЛОВИНЫ ХІХ ВЕКА
}

\section{INDUSTRIAL ENTREPRENEURSHIP OF PEASANTS IN THE COUNTY TOWNS OF TULA PROVINCE IN THE SECOND HALF OF THE $19^{\text {TH }}$ CENTURY}

\section{N. Bilenko}

Summary: The article is devoted to the analysis of the forms, scales and trends of the development of peasant industrial entrepreneurship in the county towns of Tula province in the second half of the 19th century - a province of the Russian Empire that combined the features of the Central Industrial and Central agricultural economic regions. Based on the analysis of mass historical sources - fiscal and administrative documentation) - «Journals of general verification of trade and industrial establishments», the dynamics of the development of peasant industrial establishments in the period under review is revealed, local features of organizational forms of industrial entrepreneurship are established, ways of managing peasants with their establishments are characterized, a comparative analysis of trends in the development of peasant industrial entrepreneurship in the provincial center and county towns is carried out. The paper characterizes the influence of formal and informal institutions on the organization of industrial establishments by peasants.

Keywords: economic history, city, peasantry, entrepreneurship, mass historical sources, post-reform Russia.
B торая половина XIX столетия в истории России традиционно характеризуется как период существенных изменений в социальной и экономической сферах жизни российского общества. Продемонстрировать масштабность и глубину этих изменений историки стремятся в своих макро- и микроисторических исследованиях через анализ определенных показателей, например, через увеличение численности городского населения, развитие частного предпринимательства, расширение практики применения наемного труда, сокращение различий в правовом положении отдельных сословий и т.д. В данном контексте, одним из индикаторов эволюции социально-экономических отношений в Российской империи второй половины XIX в. целесообразно считать развитие крестьянского предпринимательства.

В российской науке накоплен значительный опыт изучения хозяйственной неземледельческой активности крестьянства, в первую очередь, путем анализа развития кустарной промышленности [35; 36; 37; 38; 41; 46; 47].

\author{
Биленко Никита Алексеевич \\ К.и.н., дочент, Тульский государственный педагогический \\ университет им. Л.Н. Толстого \\ nikitabilenko@mail.ru
}

Аннотация: Статья посвящена анализу форм, масштабов и тенденций развития крестьянского промышленного предпринимательства в уездных городах Тульской губернии второй половины XIX В. - провинции Российской империи, сочетавшей в себе черты Центрально-промышленного и Центральноземледельческого экономических районов. На основе анализа массовых исторических источников (фискально-административной документации) «Журналов генеральной поверки торговли и промышленных заведений» выявляется динамика развития крестьянских промышленных заведений, устанавливаются локальные особенности организационных форм промышленного предпринимательства, характеризуются способы управления крестьянами своими заведениями, проводится сравнительный анализ тенденций развития крестьянского промышленного предпринимательства в губернском центре и уездных городах.

Ключевые слова: экономическая история, город, крестьянство, предпринимательство, массовые исторические источники, пореформенная Россия.
Однако сами историки признают, что кустарные промыслы не были полностью отделены от земледелия, играли вспомогательную роль в крестьянском хозяйстве, тем самым определяя временную, сезонную вовлеченность сельского населения в торгово-рыночные отношения. Не меньший интерес вызывает опыт организации крестьянами стационарных торгово-промышленных заведений (особенно в городах - традиционных центрах концентрации торговли и промышленного производства [45, с. 6], что порождало их систематическую вовлеченность в рыночные отношения, их целенаправленную хозяйственную ориентацию на рынок.

Пространственные масштабы Российской империи, климатическое и природное многообразие ее отдельных регионов обусловили множественность форм частной предпринимательской деятельности крестьян в рассматриваемый период. Данное обстоятельство повышает значимость региональных и локальных историко-экономических исследований, которые призваны не 
просто проиллюстрировать «местным», «частным» материалом макроисторические процессы, но и выявить влияние данных процессов на предпринимательскую активность крестьянства, зафиксировать ее многообразные формы, установить локальные факторы, способствовавшие вовлеченности данного социального слоя в капиталистические отношения.

Настоящее исследование посвящено анализу развития промышленного предпринимательства крестьян в уездных городах Тульской губернии второй половины XIX в. - провинции, одновременно сочетавшей в себе черты двух экономических районов - Центрально-промышленного и Центрально-земледельческого [48, с. 5-6]. На основе комплексного историко-географического анализа были выявлены особенности отдельных уездов губернии, что позволило установить их типологию [2]. Так, для северных (нечерноземных) уездов провинции (Алексинского и Каширского) типичным было наличие малоплодородных, суглинистых почв, а также активное участие проживавшего здесь крестьянского населения в отхожих промыслах (его занятость в Туле и Москве). Уезды средней полосы губернии - Белевский, Веневский, Крапивенский, Одоевский и Тульский отличались относительной плодородностью почв, широким развитием кустарных промыслов. Южные уезды (Богородицкий, Епифанский, Ефремовский, Новосильский и Чернский) обладали черноземными почвами, а большинство сельского населения здесь было занято сельскохозяйственным трудом. С целью выявления локальной специфики крестьянского промышленного предпринимательства для анализа были отобраны данные по городам, которые располагались в уездах всех трех типов, а именно сведения по Алексину, Белеву, Веневу, Епифани, Ефремову и Черни (см.: Таблицы № 1 - 3).

Основу исследования составили данные массовой фискально-административной документации - «Журналов генеральной поверки торговли и промышленных заведений», которые ежегодно составлялись чиновниками Казенных палат по результатам проведенных генеральных проверок торговли и промыслов при участии торговых депутатов городов. В работе привлечены источники, созданные в 1872, 1876, 1880, 1884, 1888 гг. Их выбор обусловлен наибольшей степенью сохранности корпуса архивных документов, а шаг в 4 года позволяет установить динамику и выявить тенденции развития промышленного предпринимательства крестьян в уездных городах. Журналы содержат сведения о формах и размерах промышленных заведений, их собственниках, лицах, непосредственно осуществлявших управление предприятиями, документах, на основании которых осуществлялся торг или промысел, ассортименте производимых товаров. Сведения Журналов достаточны, чтобы внешне охарактеризовать каждое промышленное предприятие, что недостижимо при анализе обезличенных статистических сведений, содержащихся, к примеру, в отчетах губернаторов, Обзорах губерний или Памятных книжках [1]. Специфика источниковой базы обусловила применяемую в исследовании методику. Так, типовой формуляр Журналов позволяет автоматизировать обработку сведений массовых источников. Для этой цели была создана машиночитаемая источнико-ориентированная реляционная база данных «Предприниматели уездных городов Тульской губернии второй половины XIX в.» на основе СУБД Microsoft Access 2007. Результаты обработки материалов источников представлены в Таблицах 1, 2, 3.

Однако для точности исследования и обоснованности выводов следует отметить, что подсчету и анализу в статье подвергались, во-первых, предприятия, находившиеся в собственности крестьян, т.е. лиц, принадлежавших на момент их записи в источник к сословию свободных сельских обывателей и обладавших своим специфическим правовым статусом. При их переходе в иное гражданское состояние (к примеру, после их записи в купечество) данные предприятия исключались в настоящей работе из разряда крестьянских. Во-вторых, подсчету подлежали только цензовые предприятия, т.е. те промышленные заведения, которые нашли отражение в источниках. Проблема точного подсчета крестьянских промышленных заведений затрагивалась еще в 1960-е гг. П.Г. Рындзюнским, который признавал возможность при характеристике крестьянской промышленности руководствоваться лишь косвенными описательными данными источников [46, с. 75]. Специфика промыслового налогообложения в Российской империи заключалась в зависимости налогового бремени от внешних признаков предприятий - сферы промышленного производства, численности занятых на них рабочих, наличия/ отсутствия паровых двигателей, масштабности торга и т.д. В силу малых масштабов, большинство крестьянских предприятий освобождалось от уплаты налогов, и, следовательно, не фиксировались в какой-либо административной или фискальной документации. Несмотря на это, Журналы генеральной поверки торговли и промышленных заведений являются ценным историческим источником в деле изучения промышленного предпринимательства крестьян в городах империи, т.к. именно цензовые городские предприятия являются индикатором систематической вовлеченности крестьян в торгово-рыночные отношения, показателем трансформации социальных-экономических отношений в Империи.

В 1863 г. вступило в силу «Положение о пошлинах за право торговли и других промыслов», ст. 20 которого провозглашала свободу предпринимательства в России [43, ст. 20]. Новый закон уравнивал в торгово-промышленных правах крестьянство с другими сословными группами империи (купцами, мещанами, дворянами). Отныне, для открытия торгово-промышленных заведений 
требовалось приобрести торговые документы (патенты): свидетельства и билеты, соответствовавшие масштабам торга или промышленного производства. Таким образом, во второй половине XIX в. возможность крестьян участвовать в предпринимательской деятельности всецело зависела от их экономических возможностей.

Опираясь на сведения Журналов, удалось установить, что во всех исследуемых уездных городах Тульской губернии формы и сферы промышленного предпринимательства крестьян были практически идентичны (Таблица 1). В первую очередь крестьяне организовывали цензовые предприятия, относящиеся к пищевой промышленности (булочные и пекарни, крупорушки и мельницы, пряничные заведения и маслобойни), а также предприятия, специализирующиеся на производстве тканей, одежды и обуви (сапожные мастерские, синильни и красильни, предприятия портных). Несложно обнаружить, что большинство крестьянских предприятий относилось либо к тем сферам промышленного производства, которые удовлетворяли повседневные потребности городского населения (в еде и одежде), либо к тем формами хозяйственной деятельности, в которых крестьяне имели опыт, полученный при ведении собственного хозяйства в деревне.

Сведения массовых источников позволяют выявить зависимость спектра отраслей крестьянского предпринимательства в уездных центрах от развитости города и городской инфраструктуры. Так, в Белеве - втором по численности населения городе Тульской губернии фиксируется наибольшее количество сфер крестьянского предпринимательства по сравнению с остальными городами провинции. Помимо «типичных» предприятий в разное время здесь функционировали еще и бондарные, столярные заведения, прядильни, кузницы и слесарные предприятия, а также каретный завод. Тем не менее, спектр отраслей крестьянской городской промышленности даже в Белеве существенно уступал спектру, существовавшему в губернском центре - Туле, где в общей сложности в различные периоды времени действовало до 39 видов крестьянских предприятий [3, с. 55-56].

Одним из важных показателей развития крестьянского предпринимательства в уездных городах является доля крестьянских предприятий от общего количества промышленных заведений городов. Данные Таблицы 2 свидетельствуют о ярко выраженной локальной специфике. Так, наибольшая доля крестьянских промышленных предприятий фиксируется в Алексине - городе, расположенном в северном (нечерноземном) уезде, где сельское население занималось преимущественно неземледельческими отхожими промыслами и торговлей. Здесь почти треть промышленных заведений принадлежала крестьянам, причем такое положение сохранялось на протяжении всех 1870-х - 1880-х гг. В городах средней полосы губернии (Белеве и Веневе) доля крестьянских предприятий была меньше (в среднем около 15-20\%), однако крестьянская промышленность Белева отличалась большей масштабностью: количество предприятий здесь исчислялось десятками. Наличие меньшей доли крестьянских заведений, вероятно, было связано с тем, что организация цензовых торгово-промышленных заведений здесь являлась менее привлекательным делом, чем организация кустарных промыслов в сельской местности, требующих меньших капиталовложений. Совсем иная картина предстает в городах южных (черноземных) уездов губернии: в Епифани, Ефремове и Черни на протяжении всей второй половины XIX столетия фиксируется сокращение доли крестьянских предприятий в общей промышленной структуре городов. Данное обстоятельство, вероятно, связано с получением крестьянством больших экономических выгод от занятий сельским хозяйством в черноземной полосе, чем от промышленного производства.

Еще одним важным показателем развития крестьянского предпринимательства в уездных городах является масштабность промышленных заведений. К сожалению, Журналы не содержат точных и достоверных сведений об оборотах промышленных заведений, однако в описаниях предприятий содержится информация о количестве наемных рабочих. Во всех уездных городах в более чем 85\% промышленных предприятий трудилось от 1 до 4 наемных рабочих и не использовался механизация труда [6-34].

Наконец, важным в характеристике крестьянского предпринимательства является анализ моделей и способов управления крестьянами своими промышленными заведениями. Таблица 3 свидетельствует о том, что во всех уездных городах в абсолютном большинстве случаев непосредственными управленцами заведений являлись их собственники. Даже женщины-предпринимательницы предпочитали самостоятельно руководить приобретением сырья, производством и реализацией произведенных товаров. С одной стороны это обусловлено желанием собственников сократить расходы, связанные с наемным трудом, с другой - тем, что крестьяне зачастую самостоятельно выступали работниками в своих небольших заведениях. Примечательным является тот факт, что крестьяне в промышленном предпринимательстве вовсе не прибегали к помощи своих родственников, в то время как в организации торгового дела активно участвовали их сыновья и жены [3, с. 54-55; 40, с. 16-18].

Данные таблиц № 1, 2 и 3 в совокупности позволяют установить еще ряд характерных черт промышленного предпринимательства крестьян в уездных городах. Вопервых, сведения таблиц отображают нестабильность крестьянского предпринимательства. На протяжении 
Таблица 1.

Формы промышленного предпринимательства крестьян

в уездных городах Тульской губернии в 1870-х - 1880-х гг.*

\begin{tabular}{|c|c|c|c|c|c|c|c|c|c|c|c|}
\hline \multirow{3}{*}{ Города } & \multirow{3}{*}{ Заведения } & \multicolumn{10}{|c|}{ Промышленные заведения в собственности крестьян } \\
\hline & & \multicolumn{2}{|c|}{1872 г. } & \multicolumn{2}{|c|}{1876 г. } & \multicolumn{2}{|c|}{1880 г. } & \multicolumn{2}{|c|}{1884 г. } & \multicolumn{2}{|c|}{1888 г. } \\
\hline & & муж & жен & муж & жен & муж & жен & муж & жен & муж & жен \\
\hline \multicolumn{12}{|c|}{ Города северных (нечерноземных) уездов губернии } \\
\hline \multirow{7}{*}{ Алексин } & Булочная / Пекарня & 2 & - & 1 & - & - & 1 & - & 2 & - & 1 \\
\hline & Крупорушка & 1 & - & 1 & - & 1 & - & - & 1 & - & 1 \\
\hline & Мельница & - & - & 1 & - & & - & - & - & - & - \\
\hline & Сапожная мастерская & 3 & - & 2 & - & 1 & - & - & - & - & - \\
\hline & Синильное заведение & 3 & - & 3 & - & 2 & - & 1 & - & - & - \\
\hline & Швейное заведение & - & - & 1 & - & - & - & - & - & - & - \\
\hline & Столярное заведение & - & - & 1 & - & 1 & - & 1 & - & 1 & - \\
\hline \multicolumn{12}{|c|}{ Города средней полосы губернии } \\
\hline \multirow{17}{*}{ Белев } & Булочная / Пекарня & 4 & 2 & 6 & - & 6 & 1 & 4 & 1 & 6 & 1 \\
\hline & Пряничное заведение & - & - & 1 & - & 1 & - & - & - & - & - \\
\hline & Крупорушка & 2 & - & 1 & - & 3 & - & 1 & - & - & - \\
\hline & Мукомольное заведение & 1 & - & 1 & - & - & - & - & - & - & - \\
\hline & Бондарное заведение & 3 & - & - & - & 3 & - & 1 & - & - & - \\
\hline & Сапожное заведение & 6 & - & 6 & - & 2 & - & - & - & - & - \\
\hline & Портняжное заведение & - & - & - & - & - & - & 1 & - & - & - \\
\hline & Синильное заведение & 3 & - & - & - & - & - & 1 & - & - & - \\
\hline & Красильное заведение & - & - & 1 & - & 1 & - & - & - & - & - \\
\hline & Столярное заведение & 1 & - & 1 & - & 1 & - & 2 & - & 1 & - \\
\hline & Прядильное заведение & 1 & - & - & - & - & - & - & - & - & - \\
\hline & Шорник & 1 & - & - & - & - & - & - & - & - & - \\
\hline & Палашник & 1 & - & - & - & - & - & - & - & - & - \\
\hline & Серебрянник & 1 & - & - & - & - & - & - & - & - & - \\
\hline & Кузница & 1 & - & 1 & - & 2 & - & 1 & - & - & - \\
\hline & Каретный завод & - & - & 1 & - & 1 & - & 1 & - & - & - \\
\hline & Слесарное заведение & - & - & - & - & 1 & - & - & - & - & - \\
\hline \multirow{6}{*}{ Венев } & Булочная / Пекарня & 1 & - & 1 & - & - & - & - & - & 1 & - \\
\hline & Маслобойня & - & - & 1 & - & - & - & - & - & - & - \\
\hline & Табачная артель & 1 & - & - & - & - & - & - & - & - & - \\
\hline & Сапожная мастерская & - & - & 1 & - & - & - & - & - & - & - \\
\hline & Красильное заведение & - & - & 1 & - & 1 & - & - & 1 & - & - \\
\hline & Кузница & - & - & 1 & - & 1 & - & 3 & - & - & - \\
\hline \multicolumn{12}{|c|}{ Города южных (черноземных) уездов губернии } \\
\hline \multirow{2}{*}{ Епифань } & Пекарня & \multirow{2}{*}{\multicolumn{2}{|c|}{$\begin{array}{c}\text { Данные отсут- } \\
\text { ствуют }\end{array}$}} & 1 & - & - & - & - & - & - & - \\
\hline & Синильное заведение & & & 2 & - & 2 & - & 1 & - & - & - \\
\hline \multirow{5}{*}{ Ефремов } & Сапожное заведение & \multirow{5}{*}{\multicolumn{2}{|c|}{$\begin{array}{c}\text { Данные отсут- } \\
\text { ствуют }\end{array}$}} & - & - & 4 & - & - & - & - & - \\
\hline & Синильное заведение & & & 2 & - & 2 & - & 2 & - & - & - \\
\hline & Бочарное заведение & & & 1 & - & - & - & - & - & - & - \\
\hline & Столярное заведение & & & 2 & - & 1 & - & - & - & - & - \\
\hline & Колесное заведение & & & 1 & - & 1 & - & - & - & - & - \\
\hline \multirow{2}{*}{ Чернь } & Булочная / Пекарня & \multirow{2}{*}{\multicolumn{2}{|c|}{$\begin{array}{c}\text { Данные отсут- } \\
\text { ствуют }\end{array}$}} & - & 1 & - & 1 & - & - & - & - \\
\hline & Кузница & & & - & - & 1 & - & - & - & - & - \\
\hline
\end{tabular}

* [6, л. 189-225; 277-310; 7, л. 2-34; 8, л. 2-54; 9, л. 3-76; 10, л. 2-20; 11, л. 2-24; 12, л. 2-50; 13, л. 2-27; 14, л. 2-16; 15, л. $2-51 ; 16$, л. 2-13; 17 , л. 2-13; 18, л. 2-36; 19, л. 87-107; 20, л. 1-13; 21, л. 2-36; 22, л. 46-54; 23, л. 3-29; 24, л. 15-64; 25, л. $10-45 ; 26$, л. 16-46; 27, л. 166-180; 28, л. 6-29; 29, л. 1-42; 30, л. 9-35; 31, л. 12-30; 32, л. 9-36; 33, л. 3-104; 34, л. 3-35]. 
Таблица 2.

Доли крестьянских заведений от общего количества промышленных предприятий в уездных городах Тульской губернии в 1870 - 1880-е гг.**

\begin{tabular}{|c|c|c|c|c|c|c|}
\hline \multirow{2}{*}{ Города } & \multirow{2}{*}{ Промышленные заведения } & \multicolumn{5}{|c|}{ Количество промышленных заведений в городах } \\
\hline & & 1872 г. & 1876 г. & 1880 г. & 1884 г. & 1888 г. \\
\hline \multicolumn{7}{|c|}{ Города северных (нечерноземных) уездов губернии } \\
\hline \multirow{3}{*}{ Алексин } & в городе & 30 & 34 & 16 & 20 & 11 \\
\hline & в собственности крестьян & 9 & 10 & 6 & 5 & 3 \\
\hline & доля крестьянских от общего числа заведений в городе & $30 \%$ & $29,4 \%$ & $37,5 \%$ & $25 \%$ & $27 \%$ \\
\hline \multicolumn{7}{|c|}{ Города средней полосы губернии } \\
\hline \multirow{3}{*}{ Белев } & в городе & 153 & 104 & 84 & 62 & 37 \\
\hline & В собственности крестьян & 27 & 19 & 22 & 13 & 8 \\
\hline & доля крестьянских от общего числа заведений в городе & $17,6 \%$ & $18,3 \%$ & $26,2 \%$ & $21 \%$ & $21,6 \%$ \\
\hline \multirow{3}{*}{ Венев } & в городе & 33 & 33 & 12 & 28 & 7 \\
\hline & в собственности крестьян & 2 & 5 & 2 & 4 & 1 \\
\hline & доля крестьянских от общего числа заведений в городе & $6,1 \%$ & $15,2 \%$ & $16,7 \%$ & $14,3 \%$ & $14,3 \%$ \\
\hline \multicolumn{7}{|c|}{ Города южных (черноземных) уездов губернии } \\
\hline \multirow{3}{*}{ Епифань } & в городе & \multirow{9}{*}{ Данные } & & 22 & 27 & 21 \\
\hline & в собственности крестьян & & & 3 & 2 & 1 \\
\hline & доля крестьянских от общего числа заведений в городе & & & $13,6 \%$ & $7,4 \%$ & $4,8 \%$ \\
\hline \multirow{3}{*}{ Ефремов } & в городе & & & 70 & 61 & 57 \\
\hline & В собственности крестьян & & тствуют & 6 & 8 & 2 \\
\hline & доля крестьянских от общего числа заведений в городе & & & $8,6 \%$ & $13,1 \%$ & $3,5 \%$ \\
\hline \multirow{3}{*}{ Чернь } & в городе & & & 14 & 11 & 14 \\
\hline & в собственности крестьян & & & 1 & 2 & 0 \\
\hline & доля крестьянских от общего числа заведений в городе & & & $7,1 \%$ & $18,2 \%$ & $0 \%$ \\
\hline
\end{tabular}

** [6, л. 189-225; 277-310; 7, л. 2-34; 8, л. 2-54; 9, л. 3-76; 10, л. 2-20; 11, л. 2-24; 12, л. 2-50; 13, л. 2-27; 14, л. 2-16; 15, л. $2-51 ; 16$, л. 2-13; 17 , л. 2-13; 18 , л. 2-36; 19, л. 87-107; 20, л. 1-13; 21, л. 2-36; 22, л. 46-54; 23, л. 3-29; 24, л. 15-64; 25 , л. 10-45; 26, л. 16-46; 27, л. 166-180; 28, л. 6-29; 29, л. 1-42; 30, л. 9-35; 31, л. 12-30; 32, л. 9-36; 33, л. 3-104; 34, л. 3-35].

1870-1880-х гг. во всех уездных городах фиксируются существенные колебания численности крестьянских промышленных заведений, что свидетельствует об ориентации крестьян на краткосрочную перспективу экономической деятельности при организации «своего дела». Во-вторых, во всех населенных пунктах обнаруживаются сферы хозяйственной деятельности, которыми крестьяне перестают заниматься в рамках организации цензовых промышленных заведений: в Алексине - мукомольным и швейным делом, в Белеве - мукомольным, прядильным, ювелирным и слесарным делом, в Веневе - маслобойным и сапожным, в Епифани - выпечкой хлеба, в Ефремове - бочарным и столярным, в Черни - выпечкой хлеба и кузнечным делом. Большинство из этих форм промышленного производства возможно было организовывать в рамках кустарных промыслов или в самых незначительных масштабах, что освобождало крестьян от уплаты налогов, делало их предприятия бо- лее выгодным. В-третьих, организация промышленных заведений являлось в крестьянской среде преимущественно мужским делом. Во всех уездных городах фиксируются единичные случаи, когда женщины выступали собственницами предприятий (и то только в сфере пищевой промышленности). Во многом этому способствовало долгое сохранение в крестьянской среде патриархальных семейных отношений. Кроме того, законами XIX в. детально регламентировались многие аспекты внутрисемейной жизни в России: от порядка вступления в брак до взаимоотношений между домочадцами, что способствовало консервации патриархальных устоев, законодательно закрепляло зависимое положение жены от мужа, её обязанность повиноваться ему как главе семейства $[4$, с. 25].

Тем не менее, государство гарантировало ряд имущественных прав женщины: она обладала правом владения 
Способы управления крестьянскими промышленными заведениями в уездных городах Тульской губернии в 1870 - 1880-е гг.***

\begin{tabular}{|c|c|c|c|c|c|c|c|c|c|c|c|}
\hline \multirow{3}{*}{ Города } & \multirow{3}{*}{$\begin{array}{c}\text { Способ управления за- } \\
\text { ведениями }\end{array}$} & \multicolumn{10}{|c|}{ Промышленные заведения в собственности крестьян } \\
\hline & & \multicolumn{2}{|c|}{1872 г. } & \multicolumn{2}{|c|}{1876 г. } & \multicolumn{2}{|c|}{1880 г. } & \multicolumn{2}{|c|}{1884 г. } & \multicolumn{2}{|c|}{1888 г. } \\
\hline & & муж & жен & муж & жен & муж & жен & муж & жен & муж & жен \\
\hline \multicolumn{12}{|c|}{ Города северных (нечерноземных) уездов губернии } \\
\hline \multirow{3}{*}{ Алексин } & самостоятельно & 9 & - & 10 & - & 5 & 1 & 2 & 3 & 1 & 2 \\
\hline & с приказчиком & - & - & - & - & - & - & - & - & - & - \\
\hline & сродственниками & - & - & - & - & - & - & - & - & - & - \\
\hline \multicolumn{12}{|c|}{ Города средней полосы губернии } \\
\hline \multirow{3}{*}{ Белев } & самостоятельно & 25 & 1 & 19 & - & 21 & 1 & 12 & 1 & 7 & 1 \\
\hline & с приказчиком & - & - & - & - & - & - & - & - & - & - \\
\hline & сродственниками & - & 1 & - & - & - & - & - & - & - & - \\
\hline \multirow{3}{*}{ Венев } & самостоятельно & 2 & - & 5 & - & 2 & - & 3 & 1 & 1 & - \\
\hline & с приказчиком & - & - & - & - & - & - & - & - & - & - \\
\hline & сродственниками & - & - & - & - & - & - & - & - & - & - \\
\hline \multicolumn{12}{|c|}{ Города южных (черноземных) уездов губернии } \\
\hline \multirow{3}{*}{ Епифань } & самостоятельно & \multirow{9}{*}{\multicolumn{2}{|c|}{ Данные отсутствуют }} & 1 & - & 2 & - & 1 & - & - & - \\
\hline & с приказчиком & & & 2 & - & - & - & - & - & - & - \\
\hline & с родственниками & & & - & - & - & - & - & - & - & - \\
\hline \multirow{3}{*}{ Ефремов } & самостоятельно & & & 6 & - & 8 & - & 2 & - & - & - \\
\hline & с приказчиком & & & - & - & - & - & - & - & - & - \\
\hline & сродственниками & & & - & - & - & - & - & - & - & - \\
\hline \multirow{3}{*}{ Чернь } & самостоятельно & & & - & 1 & 1 & 1 & - & - & - & - \\
\hline & с приказчиком & & & - & - & - & - & - & - & - & - \\
\hline & с родственниками & & & - & - & - & - & - & - & - & - \\
\hline
\end{tabular}

*** $[6$, л. 189-225; 277-310; 7, л. 2-34; 8, л. 2-54; 9, л. 3-76; 10, л. 2-20; 11, л. 2-24; 12, л. 2-50; 13, л. 2-27; 14, л. 2-16; 15, л. 2-51; 16, л. 2-13; 17, л. 2-13; 18, л. 2-36; 19, л. 87-107; 20, л. 1-13; 21, л. 2-36; 22, л. 46-54; 23, л. 3-29; 24, л. 15-64; 25 , л. 10-45; 26, л. 16-46; 27, л. 166-180; 28, л. 6-29; 29, л. 1-42; 30, л. 9-35; 31, л. 12-30; 32, л. 9-36; 33, л. 3-104; 34, л. 3-35].

общим имуществом семьи и своим частным (главным образом - приданым). А с 1863 г. в соответствии с «Положением о пошлинах...» женщины получили право наравне с мужьями приобретать торговые свидетельства и билеты, то есть официально заниматься предпринимательской деятельностью. Однако крестьянская семья представляла собой, по определению О.М. Вербицкой, «маленькое абсолютистское государство». Глава семьи обладал поистине громадной властью над домочадцами, не исключая и хозяйку дома - супругу. В данных условиях, несмотря на гарантированность государством имущественных прав, женщина не была экономически самостоятельна. Глава семьи руководил работами в поле, определял обязанности членов семьи, фактически самостоятельно распоряжался собственностью. Таким образом, неформальные нормы (обычаи и традиции) фактически нивелировали для женщин права организа- ции торгово-промышленных заведений, ограничивая их предпринимательскую активность.

При рассмотрении динамики развития крестьянского предпринимательства в уездных городах Тульской губернии несложно обнаружить сокращение с середины 1870-х гг. темпов роста количества крестьянских предприятий. Во многом на это повлияли действовавшие законодательные нормы. Во второй половине XIX в. крестьяне были уравнены в торгово-промышленных правах с иными сословиями. Однако в гражданскоправовом отношении крестьянство оставалось самым неполноправным слоем населения. До отмены крепостного права в России продолжала действовать жесткая паспортная система. В соответствии с законом 1857 г. крестьяне обязаны были проживать там, где они были записаны в подушный оклад. Покидать места постоянно- 
го проживания им разрешалось в целях торговли, по делам, связанным с работой и промыслами, но в пределах 30 верст. В остальных случаях крестьяне обязаны были приобретать паспорта или билеты на гербовой бумаге, а также виды на жительство от помещиков на срок от 1 до 6 месяцев. После отмены крепостного права в закон были внесены небольшие изменения. В частности, выдавать паспорта и увольнительные билеты стали сельские старосты и волостные старшины, а документы теперь выдавались на срок от 6 месяцев до 3 лет [42, ст. 58, 83]. Самовольный уход крестьян рассматривался в качестве побега, то есть влек за собой поиски и возвращение.

Такая «приписка» к земле фактически просуществовала до 1906 г. [39, с. 580]. Легальный уход из мест постоянного проживания делал возможным для крестьян временные заработки, в первую очередь в форме отходничества, которое во второй половине XIX в. в Тульской губернии, так же как и во всей стране, приняло значительные масштабы [44]. Однако действовавшая паспортная система, во-первых, создавала дополнительные административные препятствия, во-вторых, повышала финансовые издержки крестьян при попытках организации «своего дела», в первую очередь в городах - то есть замедляла темпы урбанизации (фактически требовалось покупать паспорта и билеты). Но, по сравнению с паспортной системой, еще большим тормозом явилось сохранение крестьянской общины. А. Гершенкрон отмечал, что отмена крепостного права могла бы создать благоприятные условия для последующей индустриализации, а малое количество земли, доставшейся крестьянину, плохое её качество способствовали бы ускорению процесса урбанизации, притоку рабочей силы в промышленность [5, с. 149]. Для того чтобы переселиться в город, крестьянин должен был выйти из общины (сельского общества) и приписаться к новому обществу. Однако выходящий обязан был навсегда отказаться от своего надела земли, выплатив за него не менее половины суммы выкупного платежа, затем погасить все недоимки казенных, земских и мирских сборов, а также уплатить окладные сборы за всех членов семьи до 1 января следующего года. После многочисленных выплат крестья- нин должен был заручиться разрешением родителей и решением схода об обеспеченности нетрудоспособных членов семейства. Кроме того, покидавший общину обязан был предоставить приемный договор того общества, в которое стремился перейти. Только после выполнения всех этих условий он мог рассчитывать на увольнительную от волостного старшины [42, ст. 130, 132-134, 139, 142]. Выполнение всех этих условий делало практически невозможным выход из общины. Даже если крестьянин собирал необходимые денежные средства, главы семейства неохотно давали разрешения на уход членам семьи. Периодически проводившееся перераспределение земли в общине находилось в зависимости от количества рабочих рук в отдельных хозяйствах. Выход члена семьи означал уменьшение надела, поэтому, по замечанию А. Гершенкрона, «каждому отдельному хозяйству приходилось сохранять избыточный фактор, т.е. количество рабочих рук, как условие получения недостаточного фактора, то есть земли» [5, с. 150].

Таким образом, анализ развития крестьянского предпринимательства в уездных городах Тульской губернии второй половины XIX в. позволяет сделать вывод о наличии в этом процессе существенных локальных особенностей. Масштабы, формы, динамика развития, специализация цензовых крестьянских промышленных предприятий зависели, во-первых, от местности, в которой располагался город (её природно-географических характеристик, близости к крупным торговым центрам и транспортным артериям, господствующим в среде крестьянского населения типом занятости - будь то отходничество или кустарные промыслы); во-вторых, от развитости самого города и его инфраструктуры (численности населения, функционального назначения населенного пункта - как административного центра или центра ремесла и торговли). По сравнению с губернским центром крестьянская промышленность в уездных городах выглядела более патриархальной: на предприятиях практически не были развиты механизация и применение наемного труда, а женщины выступали собственницами промышленных заведений лишь в исключительных случаях (например, вдовства).

\section{ЛИТЕРАТУРА}

1. Биленко Н.А. Журналы генеральной поверки торговли и промышленных заведений как исторические источники по изучению внутреннего рынка Российской империи второй половины XIX века // Современная наука: актуальные проблемы теории и практики. Серия: Гуманитарные науки. 2018. № 1. C. 4-9.

2. Биленко Н.А. Историко-географическая характеристика Тульской губернии второй половины XIX в. (к проблеме функционирования местного товарного рынка) // Университет XXI века: научное измерение: Материалы науч. конф. науч.-пед. работников, аспирантов и магистрантов ТГПУ им. Л.Н. Толстого. Тула: Изд-во Тул. гос. пед. ун-та им. Л.Н. Толстого, 2018. С. 422-433.

3. Биленко Н.А. Крестьянское предпринимательство в губернском городе Туле второй половины XIX века: формы, масштабы, тенденции развития // Ученые записки. Электронный научный журнал Курского государственного университета. 2018. № 4 (48). URL: http://scientific-notes.ru/pdf/053-008.pdf.

4. Вербицкая 0.М. Российская сельская семья в 1897-1959 гг. (историко-демографический аспект). М., Тула: Гриф и К, 2009. 296 с. 
5. Гершенкрон А. Экономическая отсталость в исторической перспективе. М.: Издательский дом «Дело» РАНХиГС, 2015. 535 с.

6. Государственное учреждение «Государственный архив Тульской области» (далее - ГУ ГАТО) Ф. 118. Оп. 1. Т. 8. Д. 17596.

7. ГУ ГАТО. Ф. 118. ОП. 1. Т. В. Д. 17598.

8. ГУ ГАТО. Ф. 118. ОП. 1. Т. 8. Д. 17599.

9. ГУ ГАТО. Ф. 118. ОП. 1. Т. 8. Д. 17602.

10. ГУ ГАТО. Ф. 118. ОП. 1. Т. 8. Д. 17646.

11. ГУ ГАТО. Ф. 118. ОП. 1. Т. 8. Д. 18138.

12. ГУ ГАТО. Ф. 118. ОП. 1. Т. 8. Д. 18139.

13. ГУ ГАТО. Ф. 118. ОП. 1. Т. 8. Д. 18141.

14. ГУ ГАТО. Ф. 118. Оп. 1. Т. 8. Д. 18142.

15. ГУ ГАТО. Ф. 118. ОП. 1. Т. 8. Д. 18143.

16. ГУ ГАТО. Ф. 118. ОП. 1. Т. 8. Д. 18148.

17. ГУ ГАТО. Ф. 118. ОП. 1. Т. 8. Д. 18684.

18. ГУ ГАТО. Ф. 118. ОП. 1. Т. 8. Д. 18685.

19. ГУ ГАТО. Ф. 118. ОП. 1. Т. 8. Д. 18689.

20. ГУ ГАТО. Ф. 118. ОП. 1. Т. 8. Д. 18692.

21. ГУ ГАТО. Ф. 118. ОП. 1. Т. 8. Д. 18693.

22. ГУ ГАТО. Ф. 118. ОП. 1. Т. 8. Д. 18697.

23. ГУ ГАТО. Ф. 118. ОП. 1. Т. 9. Д. 19328.

24. ГУ ГАТО. Ф. 118. Оп. 1. Т. 9. Д. 19329.

25. ГУ ГАТО. Ф. 118. ОП. 1. Т. 9. Д. 19336.

26. ГУ ГАТО. Ф. 118. ОП. 1. Т. 9. Д. 19337.

27. ГУ ГАТО. Ф. 118. ОП. 1. Т. 9. Д. 19338.

28. ГУ ГАТО. Ф. 118. ОП. 1. Т. 9. Д. 19343.

29. ГУ ГАТО. Ф. 118. ОП. 1. Т. 9. Д. 20317.

30. ГУ ГАТО. Ф. 118. Оп. 1. Т. 9. Д. 20318.

31. ГУ ГАТО. Ф. 118. ОП. 1. Т. 9. Д. 20320.

32. ГУ ГАТО. Ф. 118. ОП. 1. Т. 9. Д. 20324.

33. ГУ ГАТО. Ф. 118. ОП. 1. Т. 9. Д. 20326.

34. ГУ ГАТО. Ф. 118. ОП. 1. Т. 9. Д. 20328.

35. Егоров В.Г., Зозуля О.А., Моркунцов С.А., Петряев С.В. Кустарные промыслы Нижегородской губернии второй половины XIX - начала XX века. СПб.: Алетейя, 2013. 272 C.

36. Егоров В.Г., Зозуля О.А., Палеолог М.В. Кустарные промыслы нечерноземной деревни второй половины XIX - начала XX вB. (на материалах Московской губернии). М.: Ин-т диаспоры и интеграции (Ин-т стран СНГ), 2011. 446 с.

37. Егоров В.Г., Зозуля 0.А., Сарыков Е.С. Кустарные промыслы Курской губернии второй половины XIX - начала XX вв. СПб.: Алетейя, 2016. 206 с.

38. Зозуля 0.А., Антонов 0.Ю., Егоров В.Г. Кустарные промыслы Воронежской губернии второй половины XIX - начала XX века. СПб.: Алетейя, 2014. 349 с.

39. Иванова Н.А., Желтова В.П. Сословное общество Российской империи (XVIII - начало XX века). М.: Новый хронограф, 2010. 732 с.

40. Лобачева И.Н. Хозяева и управляющие: анализ социального и гендерного состава предпринимателей Тульской губернии в конце 60-х гг. XIX в. // Тульский научный вестник. Серия История. Языкознание. 2021. № 1(5). С. 6-23. [Электронный ресурc] URL: http://tula-vestnik.ru/pdf/2021/ vipusk_5_31_03_21.pdf

41. Никулин В.Н. Крестьянские промыслы на (еверо-Западе России (вторая половина XIX - начало XX века). СПб.: Дмитрий Буланин, 2017. 416 с.

42. Общее положение о крестьянах, вышедших из крепостной зависимости // ПСЗРИ. Т. XXXVI. Собр. 2. Отд. 1. № 36657, 36659.

43. Положение о пошлинах за право торговли и других промыслов 1865 г. // ПСЗРИ. Собр. 2. Отд. 1. 1865. Т. XL. № 41779.

44. Рашин А.Г. Формирование рабочего класса России. Историко-экономические очерки. М.: Социально-экономическая литература, 1958. 624 с.

45. Рожков Н.А. Город и деревня в русской истории: Краткий очерк экономической истории России. М.: ЛИБРОКОМ, 2017. 88 с.

46. Рындзюнский П.Г. Крестьяне и город в капиталистической России второй половины XIX века (Взаимоотношения города и деревни в социально-экономическом строе России). М.: Наука, 1983. 269 с.

47. Рындзюнский П.Г. Крестьянская промышленность в пореформенной России. М.: Наука, 1966. 261 с.

48. Симонова Е.В. Провинциальные города Тульской губернии в XIX веке. Тула: [б.и.], 2005. 237 с.

(c) Биленко Никита Алексеевич (nikitabilenko@mail.ru). 